\title{
Urinary excretion of glycosaminoglycans in disseminated neoplasm
}

\author{
GERALD MANLEY, LYNNE BOWER, AND ANNA ANSON \\ From the Departments of Chemical Pathology and Medical Oncology, Torbay Hospital, Torquay, Devor, \\ $U K$
}

SUMMARY Urinary glycosaminoglycan excretion was studied in 24 cases of disseminated neoplasm, 12 of which had unequivocal evidence of skeletal involvement. Urinary hydroxyproline, cetylpyridinium chloride (CPC)-precipitable uronic acid, and CPC-precipitable hexosamine were expressed as a ratio to urinary creatinine. Glycosaminoglycans contained in urine concentrated $\times 1000$ by vacuum-dialysis were separated by electrophoresis on cellulose acetate and stained with alcian blue. Of the 12 cases with clear evidence of skeletal involvement, eight $(66 \%)$ showed elevation of serum alkaline phosphatase, five $(42 \%)$ showed elevation of urinary hydroxyproline, and three $(25 \%)$ showed elevation of urinary uronic acid. It is concluded that urinary uronic acid is not a sensitive index of skeletal involvement in disseminated neoplasm.

The most striking feature of the study was the identification of a well-defined fraction indistinguishable from hyaluronic acid in seven $(58 \%)$ of the cases with evidence of skeletal involvement. Hyaluronic acid is not normally identifiable in adult human urine. The hyaluronic acid excretors showed more consistent biochemical evidence of bone disease (elevation of serum alkaline phosphatase and urinary hydroxyproline) than the non-excretors. The possibility that the urinary hyaluronic acid is derived from degradation of skeletal hyaluronic acid is discussed. An alternative explanation is that the hyaluronic acid is derived from neoplastic cells as part of a reversion of glycosaminoglycan synthesis to a more 'fetal' state, a glycosaminoglycan counterpart of the production of oncofetal antigens by neoplastic cells.

Increased urinary excretion of hydroxyproline has been reported in cases of disseminated neoplasm with secondary deposits in bone (Platt et al., 1964). It is assumed that the increase in hydroxyproline excretion is the result of increased degradation of bone collagen, and it has been proposed that urinary hydroxyproline excretion provides a better index of bone erosion than serum alkaline phosphatase (Bonadonna et al., 1966; Hosley et al., 1966). Since glycosaminoglycans are associated with collagen in bone (Herring and Kent, 1961) it was decided to study the urinary glycosaminoglycan excretion in a group of patients with disseminated neoplasm to determine whether the excretion of these molecules is also increased in the presence of neoplastic invasion of bone.

Received for publication 17 October 1977

\section{Material and methods}

Twenty-four patients with disseminated neoplasm attending the Department of Medical Oncology at Torbay Hospital were studied. Tissue diagnosis was obtained by needle-biopsy or from tissue removed at operation. Evidence of skeletal involvement was obtained by clinical examination and skeletal radiographs, serum alkaline phosphatase assay, and 24-hour urinary hydroxyproline excretion. Twenty-four-hour urinary glycosaminoglycan excretion was studied by uronic acid and hexosamine assays of glycosaminoglycans isolated by cetylpyridinium chloride (CPC) precipitation, and electrophoretic separation of urinary glycosaminoglycans concentrated by vacuum-dialysis. Control data for glycosaminoglycan excretion were drawn from 100 normal subjects of all ages studied by identical methods previously reported (Manley et al., 1968). 
SERUM ALKALINE PHOSPHATASE

The method of Morgenstern et al. (1965) was employed, using a Technicon SMA-plus analyser.

URINE CREATININE

A single-channel Technicon Auto-Analyzer was used (AAI) employing Technicon method N-116 (alkaline picrate).

HYDROXYPROLINE ASSAY

Aliquots of 24-hour urine collections were assayed by the Hypronosticon Kit (Organon (Teknika) Limited, Cromwell Road, St. Neots, Huntingdon) based on the method of Goverde and Veenkamp (1972).

ISOLATION OF GLYCOSAMINOGLYCANS Glycosaminoglycans were isolated from aliquots of 24-hour urine samples by CPC precipitation, followed by dissolution of the complex in sodium chloride and final precipitation in ethanol, according to the method of Manley et al. (1968).

URONIC ACID ASSAY

Glycosaminoglycans isolated from aliquots of urine $(5 \mathrm{ml})$ were dissolved in water $(1 \mathrm{ml})$, and the uronic acid content was determined by the method of Bitter and Muir (1962).

HEXOSAMINE ASSAY

Glycosaminoglycans isolated from aliquots of urine $(5 \mathrm{ml})$ were hydrolysed with $\mathrm{HCl}(4 \mathrm{M})$ in sealed glass ampoules in an autoclave at 15 psi for $30 \mathrm{~min}$, as described by Sobocinski et al. (1976). Hydrolysates were dried over $\mathrm{KOH}$ in vacuo, and hexosamine was assayed by Boas' (1953) modification of the Elson-Morgan reaction, as described by Manley and Williams (1969).

SEPARATION OF GLYCOSAMINOGLYCANS Aliquots $(50 \mathrm{ml})$ of 24-hour urine samples were concentrated $\times 1000$ by vacuum-dialysis. Electrophoresis of urine concentrates $(10 \mu \mathrm{l}$, equivalent to $10 \mathrm{ml}$ original urine) was carried out on cellulose acetate membrane in veronal-acetate buffer, $\mathrm{pH}$ 9.2. Marker samples of hyaluronic acid (human umbilical cord), heparan sulphate (human aorta), and chondroitin sulphate (human aorta) were run alongside urine concentrates. Glycosaminoglycan fractions were located by staining with alcian blue, and quantitated by reflectance densitometry using the Joyce Chromoscan. The method was described in detail by Manley and Williams (1969).
TESTICULAR HYALURONIDASE DIGESTION

Urine concentrate $(10 \mu \mathrm{l})$ and testicular hyaluroni- $\underline{\underline{\sigma}}$ dase solution $(10 \mu \mathrm{l}$, containing ovine testicular hyaluronidase (British Drug Houses Limited) $\stackrel{5}{\rightarrow}$ $10 \mathrm{mg}$ in $0.9 \% \mathrm{w} / \mathrm{v} \mathrm{NaCl}$ ) were mixed and incubated at $37^{\circ} \mathrm{C}$ for four hours. Control 'digests' of urine 흘 concentrate $(10 \mu \mathrm{l})$ and $\mathrm{NaCl}$ solution $\left(0.9 \% \mathrm{w} / \mathrm{v}, \frac{\bar{D}}{\vec{D}}\right.$ $10 \mu$ l) were treated in the same way. Digests and $\stackrel{\mathbb{Q}}{\mathscr{Q}}$ controls $(10 \mu \mathrm{l})$ were examined side-by-side by electrophoresis on cellulose acetate membrane, as $\overrightarrow{0}$ described above.

STREPTOMYCES HYALURONIDASE DIGESTION Urine concentrate $(20 \mu \mathrm{l})$ and streptomyces hyaluro- $\frac{}{8}$ nidase solution $(10 \mu \mathrm{l}$ containing streptomyces $\dot{\omega}$ hyaluronidase (Miles Research Products Limited) ir $10 \mathrm{TRU}$, in $0.9 \% \mathrm{w} / \mathrm{v}$ sodium chloride solution) were mixed and incubated at $37^{\circ} \mathrm{C}$ for 24 hours. Saline control samples $(20 \mu \mathrm{l}$ urine concentrate plus 을 $10 \mu 10.9 \% \mathrm{NaCl}$ ) were treated in the same way. Digests and controls $(10 \mu \mathrm{l})$ were examined side-by- $\overline{\mathrm{z}}$ side by electrophoresis on cellulose acetate membrane, as described above.

\section{Results}

The major results of this study are shown in the Table. Of the 24 cases of disseminated neoplasm, 12 $(50 \%)$ showed unequivocal radiological and/or clinical evidence of skeletal involvement by the neoplasm. Of these, eight $(66 \%)$ showed raised serum alkaline phosphatase, five $(42 \%)$ showed increased urinary excretion of hydroxyproline, and three $(25 \%)$ showed increased urinary excretion of uronic acid.

If increased urinary excretion of hydroxyproline $\dot{0}$ was taken as the criterion for skeletal involvement by neoplasm, the number of cases with skeletal in- $\delta$ volvement was seven ( $29 \%$ of the total), and, of these, four $(57 \%)$ showed increased excretion of 옹 uronic acid.

Of the 12 cases with no clear radiological and/or clinical evidence of skeletal involvement by neoplasm, $N$ six $(50 \%)$ showed raised alkaline phosphatase, two o $(17 \%)$ showed increased urinary hydroxyproline $N$ excretion, and four $(33 \%)$ showed increased $\mathcal{\omega}^{\circ}$ urinary uronic acid excretion. However, it might be 0 misleading to place too much emphasis on these 0 figures, since it is impossible to be certain that the skeleton was not involved by neoplasm in these $\stackrel{f}{?}$ cases.

The correlation between urinary hydroxyproline and uronic acid excretion was poor. Of the seven cases with increased urinary hydroxyproline excretion, three $(43 \%)$ did not show increased urinary uronic acid excretion, and of the seven cases with 
able Clinical and biochemical data on 24 cases of disseminated neoplasm

\begin{tabular}{|c|c|c|c|c|c|c|c|c|c|c|c|c|c|}
\hline \multirow[t]{2}{*}{ ase } & \multirow[t]{2}{*}{ Sex } & \multirow[t]{2}{*}{ Age } & \multirow[t]{2}{*}{ Diagnosis } & \multirow[t]{2}{*}{ Treatment* } & \multirow[t]{2}{*}{$\begin{array}{l}\text { Skeletal } \\
\text { metastases }\end{array}$} & \multirow{2}{*}{$\begin{array}{l}\text { Serum } \\
\text { Alk. Phos. } \\
(I U / l) \\
(N: 20-90)\end{array}$} & \multirow{2}{*}{$\begin{array}{l}\text { Urinary } \\
\text { Hxypro/ } \\
\text { creat } \\
(\mathrm{mmol} / \mathrm{mol}) \\
(N: 3-31)\end{array}$} & \multirow{2}{*}{$\begin{array}{l}\text { Urinary } \\
\text { UA/creat } \\
(\mathrm{mmol} / \mathrm{mol}) \\
(\mathrm{N}: 0 \cdot 3: 2 \cdot 8)\end{array}$} & \multicolumn{4}{|c|}{$\begin{array}{l}\text { Urinary electrophoresis } \\
\% \text { total } A B+v e \text { material }\end{array}$} & \multirow{2}{*}{$\begin{array}{l}\text { Streptomyces } \\
\text { hyaluronidase } \\
\text {-lability }\end{array}$} \\
\hline & & & & & & & & & $\begin{array}{l}\text { Fraction } \\
\text { E3 }\end{array}$ & $\begin{array}{l}\text { Fraction } \\
\text { EX }\end{array}$ & $\begin{array}{l}\text { Fraction } \\
\text { E2 }\end{array}$ & $\begin{array}{l}\text { Fraction } \\
\text { EI }\end{array}$ & \\
\hline . & $\mathbf{F}$ & 78 & IgA myeloma & $\mathrm{C}, \mathbf{X}, \mathbf{S t}$ & + & 55 & 19 & $1 \cdot 85$ & $28 \cdot 5$ & $7 \cdot 3$ & $16 \cdot 6$ & $47 \cdot 6$ & $\begin{array}{l}+ \text { (fraction } \\
\text { EX) }\end{array}$ \\
\hline : & $\mathbf{F}$ & 61 & Ca. ovary & C & - & 75 & 12 & 1.09 & $32 \cdot 6$ & 0 & 23 & $44 \cdot 4$ & 0 \\
\hline i & $\mathbf{F}$ & 52 & Ca. breast & C & + & 230 & 28 & $1 \cdot 45$ & $9 \cdot 1$ & $4 \cdot 8$ & 20 & $66 \cdot 1$ & $\begin{array}{l}+ \text { (fraction } \\
\text { EX) }\end{array}$ \\
\hline$\vdots$ & $\mathbf{M}$ & 62 & IgG myeloma & $\mathrm{C}, \mathbf{S t}$ & - & 45 & 21 & $2 \cdot 20$ & $24 \cdot 8$ & 0 & $28 \cdot 4$ & $46 \cdot 8$ & 0 \\
\hline ; & $\mathbf{M}$ & 71 & IgG myeloma & 0 & - & 50 & 12 & $1 \cdot 24$ & $34 \cdot 9$ & 0 & 21 & $44 \cdot 1$ & 0 \\
\hline ; & $\mathbf{F}$ & 70 & Ca. breast & $\mathrm{C}, \mathrm{Su}, \mathrm{X}$ & - & 62 & 27 & 1.59 & $21 \cdot 7$ & $\mathbf{0}$ & $13 \cdot 7$ & $64 \cdot 6$ & 0 \\
\hline ; & $\mathbf{F}$ & 65 & Ca. breast & $\mathrm{Su}, \mathrm{X}, \mathrm{C}$ & + & 100 & 58 & 1.87 & 30.6 & $3 \cdot 5$ & $14 \cdot 7$ & $51 \cdot 2$ & $\begin{array}{l}+ \text { (fraction } \\
\text { EX) }\end{array}$ \\
\hline 3 & $\mathbf{M}$ & 48 & IgG myeloma & C & + & 33 & 17 & 1.64 & $23 \cdot 9$ & 0 & $26 \cdot 5$ & $49 \cdot 6$ & 0 \\
\hline i & $\mathbf{F}$ & 56 & Ca. ovary & C & - & 125 & 44 & $6 \cdot 79$ & $13 \cdot 4$ & $\mathbf{0}$ & $53 \cdot 1$ & $33 \cdot 5$ & 0 \\
\hline ) & $\mathbf{F}$ & 50 & Ca. ovary & $\mathrm{C}, \mathrm{Su}, \mathrm{X}$ & - & 102 & 21 & 1.06 & $36 \cdot 2$ & 0 & $18 \cdot 9$ & $44 \cdot 9$ & 0 \\
\hline$!$ & $\mathbf{F}$ & 60 & Ca. ovary & 0 & + & 156 & 41 & $15 \cdot 2$ & $13 \cdot 9$ & $4 \cdot 7$ & $21 \cdot 9$ & $59 \cdot 5$ & $\begin{array}{l}+ \text { (fraction } \\
\text { EX) }\end{array}$ \\
\hline ? & $\mathbf{F}$ & 58 & Ca. breast & $\mathrm{Su}, \mathrm{X}, \mathrm{C}$ & + & 51 & 27 & 0.86 & $27 \cdot 3$ & 0 & $24 \cdot 1$ & $48 \cdot 6$ & 0 \\
\hline 3 & $\mathbf{F}$ & 60 & Ca. breast & $\mathrm{Su}, \mathrm{X}, \mathrm{C}$ & + & 79 & 13 & 1.63 & $27 \cdot 9$ & 0 & 17 & $55 \cdot 1$ & 0 \\
\hline i & $\mathbf{F}$ & 53 & Ca. breast & $\mathrm{Su}, \mathrm{X}, \mathrm{C}$ & + & 130 & 42 & $2 \cdot 23$ & $32 \cdot 2$ & 0 & $33 \cdot 9$ & $33 \cdot 9$ & 0 \\
\hline ; & $\mathbf{F}$ & 59 & Ca. breast & Su, X, C & - & 46 & 10 & $1 \cdot 50$ & 32.9 & 0 & $20 \cdot 5$ & $46 \cdot 6$ & 0 \\
\hline ; & $\mathbf{F}$ & 45 & Ca. breast & $\mathrm{Su}, \mathrm{C}, \mathrm{St}$ & + & 426 & 74 & $2 \cdot 35$ & $8 \cdot 3$ & $5 \cdot 3$ & $33 \cdot 7$ & $52 \cdot 7$ & $\begin{array}{l}+(\text { fraction } \\
\text { EX) }\end{array}$ \\
\hline$\frac{7}{3}$ & $\begin{array}{l}\mathbf{M} \\
\mathbf{F}\end{array}$ & $\begin{array}{l}34 \\
45\end{array}$ & Ca. caecum & $\mathrm{Su}, \mathrm{C}$ & - & 697 & 22 & 1.52 & $15 \cdot 5$ & 0 & 40 & $44 \cdot 5$ & 0 \\
\hline & $\mathbf{F}$ & 43 & mono. leukaemia & $\mathrm{Su}, \mathrm{X}$ & - & 31 & 22 & $5 \cdot 38$ & $34 \cdot 0$ & 0 & 66 & 0 & 0 \\
\hline ? & $\mathbf{F}$ & 71 & Ca. breast & $\mathrm{X}, \mathrm{C}, \mathrm{St}$ & - & 257 & 31 & $4 \cdot 21$ & $41 \cdot 0$ & 0 & $14 \cdot 1$ & 44.9 & \\
\hline ) & $\mathbf{F}$ & 51 & Ca. breast & $\mathrm{Su}, \mathbf{X}, \mathbf{C}$ & - & 142 & 31 & 0.89 & 43.6 & 0 & $18 \cdot 2$ & $38 \cdot 2$ & \\
\hline$i$ & $\mathbf{M}$ & 57 & Ca. colon & $\mathrm{C}, \mathrm{Su}$ & + & 1000 & 51 & $9 \cdot 88$ & $14 \cdot 4$ & $5 \cdot 0$ & $43 \cdot \overline{3}$ & $37 \cdot 3$ & $\begin{array}{l}+(\text { fraction } \\
\text { EX) }\end{array}$ \\
\hline$?$ & $\mathbf{M}$ & 71 & IgA myeloma & $\mathrm{X}, \mathrm{C}, \mathrm{St}$ & + & 185 & 14 & 1.07 & $40 \cdot 1$ & $\mathbf{0}$ & $16 \cdot 6$ & $43 \cdot 3$ & 0 \\
\hline 3 & $\mathbf{M}$ & 59 & IgA myeloma & $\mathrm{X}, \mathrm{C}, \mathrm{St}$ & + & 116 & 28 & $4 \cdot 3$ & $26 \cdot 8$ & $9 \cdot 8$ & $26 \cdot 2$ & $37 \cdot 2$ & $\begin{array}{l}+(\text { fraction } \\
\text { EX) }\end{array}$ \\
\hline 1 & $\mathbf{F}$ & 30 & $\begin{array}{l}\text { Turner's } \\
\text { syndrome, } \\
\text { embryonal } \\
\text { abdominal } \\
\text { tumour }\end{array}$ & 0 & - & 99 & 37 & 3.97 & $38 \cdot 8$ & 0 & $21 \cdot 3$ & 39.9 & 0 \\
\hline
\end{tabular}

$\mathrm{C}=$ chemotherapy $\mathbf{X}=$ radiotherapy $\mathbf{S t}=$ steroid therapy; $\mathrm{Su}=$ surgery; $0=$ no treatment.

- Clear radiological and/or clear clinical evidence of skeletal involvement.

- No clear evidence of skeletal involvement (not necessarily no skeletal involvement).

onversion: SI to traditional units- Hydroxyproline $/$ creatinine: $\mathrm{mg} / \mathrm{g}=\mathrm{mmol} / \mathrm{mol} \times 1 \cdot 16$. Uronic acid $/ \mathrm{creatinine:} \mathrm{mg} / \mathrm{g}=\mathrm{mmol} / \mathrm{mol} \times 1 \cdot 72$

increased urinary uronic acid excretion, three $(43 \%)$ did not show increased urinary hydroxyproline excretion.

The urinary hexosamine:creatinine ratio was generally slightly higher than the uronic acid: creatinine ratio. The correlation between urinary uronic acid and hexosamine excretion was good, all cases with increased uronic acid excretion showing a similar increase in hexosamine excretion (Fig. 1).

Electrophoresis of urine concentrate produced the three alcian blue-positive fractions described by Manley et al. (1968) in 23 of the 24 cases (96\%), fraction E1 corresponding with shondroitin and dermatan sulphates, fraction E2 corresponding with heparan sulphates, and the complex fraction E3 corresponding with glycoproteins (Figs 2 and 3). Testicular hyaluronidase digestion destroyed approximately $80 \%$ of fraction E1, indicating the low content of dermatan sulphate. Fractions E2 and E3 were resistant to digestion by testicular hyaluronidase.

Cases of increased urinary uronic acid excretion did not show a consistent pattern on electrophoresis of urinary glycosaminoglycans. It was not possible to attribute the increased uronic acid excretion to an increase in any one alcian blue-positive electrophoretic fraction.

The most unexpected and striking finding on electrophoresis of the urinary glycosaminoglycans was the appearance of a well-defined fraction, which is not normally identifiable by these methods in adult human urine (Manley et al., 1968). This fraction (EX) occurred as a sharply defined alcian bluepositive band in seven of the 24 urine samples $(29 \%)$. The electrophoretic mobility of this fraction was. identical with that of the hyaluronic acid identified in neonatal urine (Manley et al., 1968), hyaluronic acid from human umbilical cord (Manley et al., 1968) 


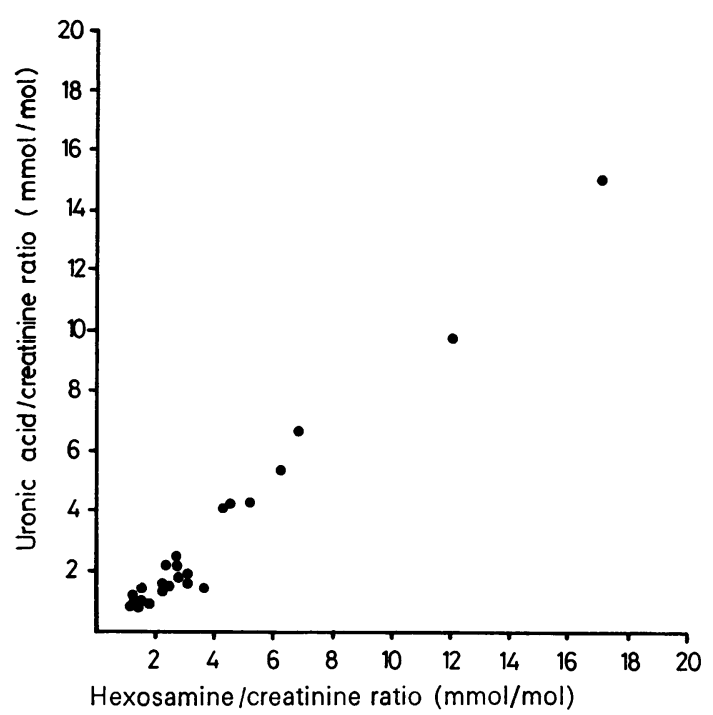

Fig. 1 Urinary CPC-precipitable uronic acid/ creatinine and CPC-precipitable hexosamine/ creatinine ratios in the 24 cases of disseminated neoplasm, showing the approximately linear relationship between these two parameters of urinary glycosaminoglycan excretion.

and hyaluronic acid from human aorta (Manley, 1965). It was destroyed by digestion with testicular hyaluronidase and streptomyces hyaluronidase (Table). Fraction EX was not identified in the 12 cases with no clear evidence of skeletal involvement but occurred in seven $(58 \%)$ of the 12 cases showing clear evidence of neoplastic involvement of bone.

Within the group showing clear evidence of skeletal secondaries, the 'hyaluronic acid excretors' differed from the 'non-excretors' in showing a more consistent elevation of serum alkaline phosphatase (86\% of hyaluronic acid excretors compared with $40 \%$ of non-excretors), urinary hydroxyproline (57\% compared with $20 \%$ ), and urinary uronic acid ( $43 \%$ of excretors compared with $0 \%$ non-excretors).

No clear correlation was found between the biochemical parameters included in this study and the treatment the patients were undergoing (Table).

\section{Discussion}

The primary premise of this study-that neoplastic invasion of bone might result in an increase in urinary glycosaminoglycan excretion as well as urinary hydroxyproline excretion-has been partially confirmed, but it is clear that not all cases showing increased hydroxyproline excretion also show an increased glycosaminoglycan excretion. If urinary hydroxyproline excretion is accepted as an $\frac{0}{\overrightarrow{5}}$ index of bone resorption in metastatic neoplasm $\frac{\text { - }}{-}$ (Bonadonna et al., 1966), it appears that urinary $\overrightarrow{\vec{s}}$ uronic acid is a less sensitive index, since only $57 \%$ of cases with an increased hydroxyproline excretion $\frac{C}{0}$ showed an increased uronic acid excretion. On the $\frac{\bar{c}}{\bar{D}}$ basis of this study, urinary uronic acid excretion $\vec{\nabla}$ cannot be recommended as an alternative to urinary $\stackrel{2}{2}$ hydroxyproline excretion for the assessment of bone $\mathrm{w}$ resorption in metastatic neoplasm.

One case in this study (case 18) showed an increase in urinary uronic acid excretion without any $\vec{\omega}$ evidence of bone resorption as judged by clinical evidence, $x$-ray studies, serum alkaline phosphatase, and urinary hydroxyproline excretion. However, $\vec{\omega}$ bone was involved in the neoplastic process, as $r$ shown by sternal marrow biopsy, which revealed sheets of leukaemic cells. The urinary glycosamino- 0 glycan excretion in this case was most atypical, there being a large fraction corresponding with heparan $\vec{z}$ sulphates (E2) and no detectable fraction corresponding with chondroitin sulphates (E1). Glycosamino- glycans have been isolated from blood leucocytes (Fedorko and Morse, 1965), and it is possible that excess glycosaminoglycans may be produced by leukaemic cells. It is also possible that the absence of chondroitin sulphates could be due to the liber- $\bar{\partial}$ ation of degradative lysosomal enzymes from $\stackrel{2}{\circ}$ leukaemic cells. The subject of urinary glyco- $\stackrel{\mathbb{Q}}{\varrho}$ saminoglycan excretion in leukaemia may well repay $\overrightarrow{\overrightarrow{0}}$ further study.

The molar ratio of hexosamine to uronic acid in the glycosaminoglycans precipitated from urine by을 CPC was slightly in excess of unity. This was probably due to the presence of traces of keratan? sulphate, which contains hexosamine but no uronic 3 acid.

It is interesting to note that, of the four cases of myeloma with clear radiological evidence of bone resorption, only two showed even a slight increase $\stackrel{5}{5}$ in serum alkaline phosphatase, only one showed an $\frac{D}{O}$ increase in urinary uronic acid excretion and none showed an increase in urinary hydroxyproline excre- $N$ tion. Possibly the mechanism of bone resorption in $\mathrm{N}$ myeloma differs from that of other neoplasms.

The most interesting and remarkable outcome of ${ }^{\omega}$ this study was the discovery of a fraction indistinguishable from hyaluronic acid in urine from seven of the 12 cases with neoplastic involvement of bone. Although the presence of hyaluronic acid is a fea- ture of neonatal urine (Manley et al., 1968), and is present in high concentration in fetal connective $\frac{\vec{D}}{\mathbb{D}}$ tissues, its concentration in most connective tissues? (such as vascular tissue (Manley, 1965)) declines 2 throughout adult life and is not normally identi-? fiable as a separate fraction in adult human urine by 


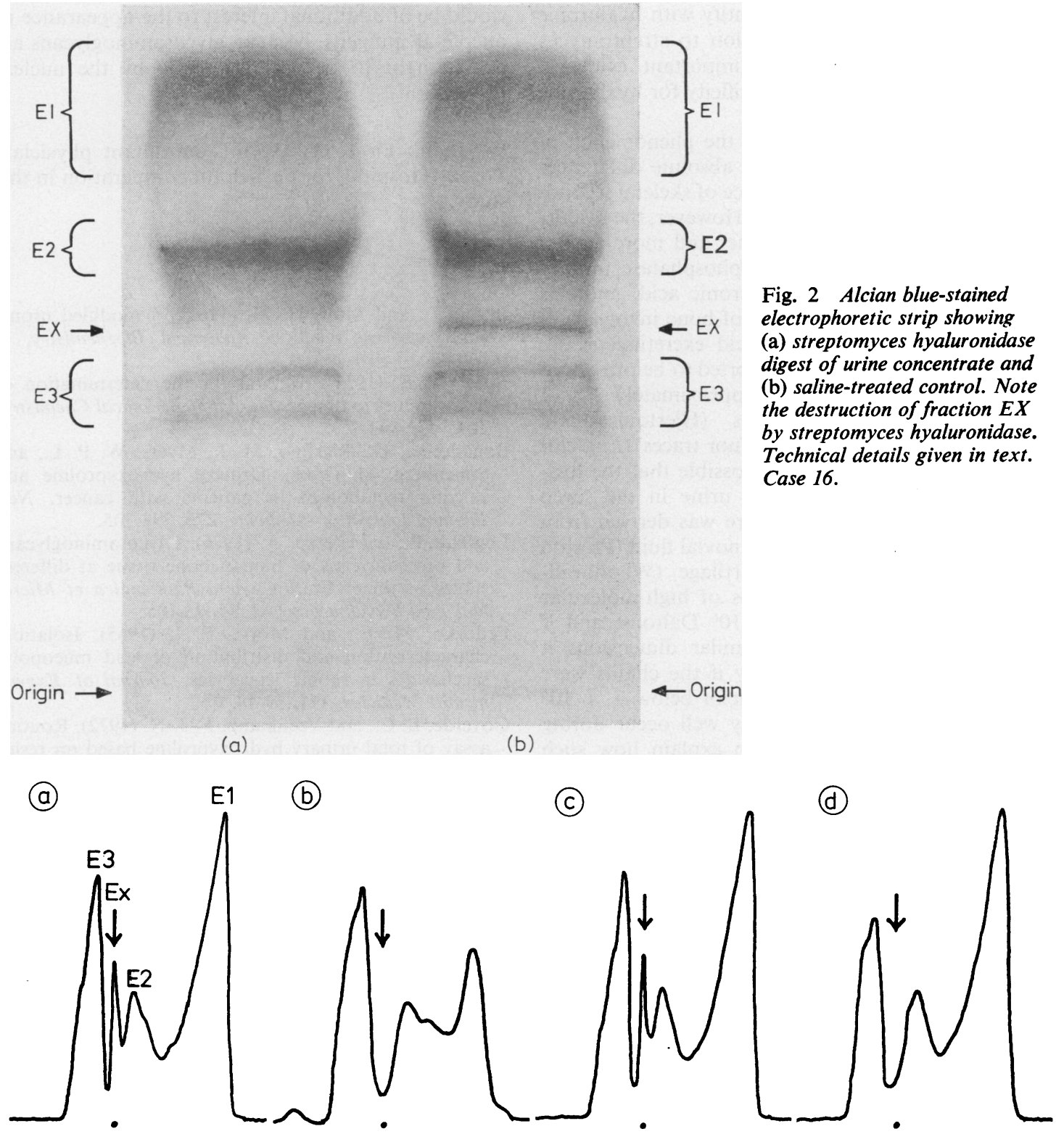

Fig. 3 Chromoscan traces of alcian blue-positive fractions (E1, E2, EX, and E3) on cellulose acetate electrophoresis of urine concentrate: (a) saline-treated control; (b) testicular hyaluronidase digest; (c) saline-treated control;

(d) streptomyces hyaluronidase digest. Electrophoretic migration from left to right. The vertical arrow above the trace, and the spot beneath it, mark the position of a marker sample of hyaluronic acid from human umbilical cord.

Technical details are given in the text. Case 1.

the techniques used in this study (Manley et al., 1968). Excretion of significant amounts of hyaluronic acid in adult human urine has been reported in the rare Werner's syndrome (Tokunaga et al., 1975) which, paradoxically, is associated with premature ageing.
Although fraction EX was not recovered in sufficient quantity to allow definitive analysis, its identical electrophoretic mobility with hyaluronic acid from human umbilical cord, neonatal urine, and aorta, its staining reaction with alcian blue, and its lability to both testicular and streptomyces hyalur- 
onidase give support to its identity with hyaluronic acid. The lability of this fraction to streptomyces hyaluronidase is particularly important evidence, since this enzyme has high specificity for hyaluronic acid (Ohya and Kaneko, 1970).

The group of cases showing the phenomenon of hyaluronuria showed no other absolute differences from the cases with clear evidence of skeletal secondaries but without hyaluronuria. However, the hyaluronic acid excretors showed higher and more consistent elevation of serum alkaline phosphatase, urinary hydroxyproline, and urinary uronic acid, and this might suggest a greater degree of bone involvement than in the non-hyaluronic acid excreting group.

Hyaluronic acid has been reported to be present in low concentrations in bone (approximately 3\% of the total glycosaminoglycans (Hjertquist and Vejlens, 1966), and 'possibly minor traces' (Engfeldt and Hjerpe, 1976)), and it is possible that the hyaluronic acid appearing in the urine in the seven cases of neoplasm reported here was derived from bone. The hyaluronic acid of synovial fluid (Preston et al., 1965) and hyaline cartilage (WoodheadGalloway and Hukins, 1976) is of high molecular weight, probably in excess of $10^{6}$ Daltons, and if bone hyaluronic acid is of similar dimensions it could appear in the urine only if the chains were degraded to a molecular weight of below $7 \times 10^{4}$ Daltons. Such degradation may well occur during osteolysis, but it is difficult to explain how such significant amounts of hyaluronic acid appear in the urine when the reported concentration of hyaluronic acid in bone is so low.

An alternative explanation is that hyaluronic acid may be produced by neoplastic cells. Hyaluronic acid has been identified in mesothelioma tissue (Preston et al., 1965; Motomiya et al., 1975) and in breast tumours (Takeuchi et al., 1976). Further studies are required to determine whether the urinary hyaluronic acid identified in cases of disseminated neoplasm is of skeletal or tumour origin.

Hyaluronic acid may be regarded as a characteristically 'fetal' glycosaminoglycan, and the reversion of a neoplastic cell to a 'fetal' type of glycosaminoglycan synthesis would be a most interesting phenomenon in the context of cancer biology. Several protein-based molecular species which are normally present in the fetus but disappear in the adult (for example, carcinoembryonic antigen, alphafetoprotein) may reappear as a result of synthesis by neoplastic cells. It is possible that the appearance of hyaluronic acid in the urine of some adults with disseminated neoplasm is an analogous phenomenon. If this proves to be the case, it would be another example of the reversion of a neoplastic cell to a more primitive (less differentiated) state, but would be of additional interest to the appearance of oncofetal antigens, because glycosaminoglycans are not thought to be coded directly by the nuclear DNA.

We thank Dr I. G. McGill, consultant physician Torbay Hospital, for his helpful co-operation in thisD study.

\section{References}

Bitter, T., and Muir, H. M. (1962). A modified uronic acid carbazole reaction. Analytical Biochemistry, 4\% 330-334.

Boas, N. F. (1953). Method for the determination of hexosamines in tissues. Journal of Biological Chemistry: 204, 553-563.

Bonadonna, G., Merlino, M. J., Myers, W. P. L., and Sonenberg, M. (1966). Urinary hydroxyproline and calcium metabolism in patients with cancer. $\mathrm{New}_{\overline{7}}$ England Journal of Medicine, 275, 298-305.

Engfeldt, B., and Hjerpe, A. (1976). Glycosaminoglycans and proteoglycans of human bone tissue at differente stages of mineralization. Acta Pathologica et Micro biologica Scandinavica (A), 84, 95-106.

Fedorko, M. E., and Morse, S. I. (1965). Isolation, characterization and distribution of acid mucopolysaccharides in rabbit leucocytes. Journal of Experimental Medicine, 121, 39-48.

Goverde, B. C., and Veenkamp, F. J. N. (1972). Routine assay of total urinary hydroxyproline based on resin catalysed hydrolysis. Clinica Chimica Acta, 41, 29-40을

Herring, G. M., and Kent, P. W. (1961). Acid mucosubstances of cortical bone (Abstract). Biochemical Journal, 81, $1 \mathrm{p}$.

Hjertquist, S. O., and Vejlens. L. (1966). The glycosaminoglycans of compact bone tissue and epiphysea? cartilage in normal dogs and in dogs treated with parathyroid extract. Studies using a column procedure with cetylpyridinium chloride. In 4th European Symposium on Calcified Tissues (International Congress Series No. 120), edited by P. J. Gaillard, A. van den음 Hooff, and R. Steendijk, p. 55. Excerpta Medica, Amster-I dam.

Hosley, H. F., Taft, E. G., Olson, K. B., Gates, S., and Beebe, R. T. (1966). Hydroxyproline excretion ino malignant neoplastic disease. Archives of Internaliv Medicine, 118, 565-571.

Manley, G. (1965). Changes in vascular mucopoly-w saccharides with age and blood pressure. British Journal of Experimental Pathology, 46, 125-134.

Manley, G., Severn, M., and Hawksworth, J. (1968). Excretion patterns of glycosaminoglycans and glyco-proteins in normal human urine. Journal of Clinical $i_{\square}$ Pathology, 21, 339-345.

Manley, G., and Williams, U. (1969). Urinary excretion of glycosaminoglycans in the various forms of gar- $\frac{?}{\Phi}$ goylism. Journal of Clinical Pathology, 22, 67-75.

Morgenstern, S., Kessler, G., Auerbach, J., Flor, R. V., and Klein, B. (1965). An autormated p-nitrophenyl-o 
phosphate serum alkaline phosphatase procedure for the Auto-Analyzer. Clinical Chemistry, 11, 876-888.

Motomiya, M., Endo, M., Arai, H., Yokosawa, A., Sato, H., and Konno, K. (1975). Biochemical characterization of hyaluronic acid from a case of benign, localised, pleural mesothelioma. American Review of Respiratory Disease, 111, 775-780.

Ohya, T., and Kaneko, Y. (1970). Novel hyaluronidase from streptomyces. Biochimica Biophysica Acta, 198, 607-609.

Platt, W. D., Doolittle, L. H., and Hartshorn, J. W. S. (1964). Urinary hydroxyproline excretion in metastatic cancer of bone. New England Journal of Medicine, 271, 287-290.

Preston, B. N., Davies, M., and Ogston, A. G. (1965). The composition and physicochemical properties of hyaluronic acids prepared from ox synovial fluid and from a case of mesothelioma. Biochemical Journal, 96, 449-474.

Sobocinski, P. Z., Canterbury, W. J., and Jurgens, K. H. (1976). Improved continuous-flow method for determination of total serum hexosamines. Clinical Chemistry, 22, 1394-1396.

Takeuchi, J., Sobue, M., Sato, E., Shamoto, M., Miura, K., and Nakagaki, S. (1976). Variations in glycosaminoglycan components of breast tumours. Cancer Research, 36, 2133-2139.

Tokunaga, M., Futami, T., Wakamatsu, E., Endo, M., and Yosizawa, Z. (1975). Werner's syndrome as 'Hyaluronuria'. Clinica Chimica Acta, 62, 89-96.

Woodhead-Galloway, J., and Hukins, D. W. L. (1976). Molecular biology of cartilage. Endeavour, 35, 73-78.

Reports and Bulletins prepared by the Association of Clinical Biochemists The following reports and bulletins are published by the Association of Clinical Biochemists. They may be obtained from The Publishing Department, British Medical Journal (ACB Technical Bulletins), B.M.A. House, Tavistock Square, London WC1H 9JR. Overseas readers should remit by British Postal or Money Order.

SCIENTIFIC REVIEWS (price $£ 1 \cdot 00 / \$ 2.00$ each)

1 The assessment of thyroid function March 1971 F. V. FLYNN and J. R. HOBBS

2 Renal function tests suitable for clinical practice January 1972 F. L. MITCHELL, N. VEALL, and R. W. E. WATTS

3 Biochemical tests for the assessment of fetoplacental function May 1975 C. E. WILDE and R. E. OAKEY

4 Test of exocrine pancreatic function March 1977 A. H. GOWENLOCK

TECHNICAL BULLETINS (price $£ 1.00 / \$ 2.00$ each)

22 Bilirubin standards and the determination of bilirubin by manual and technicon AutoAnalyzer methods January 1971 BARBARA BLLING, RUTH HASLAM, and N. WALD

23 Interchangeable cells for spectrophotometers and fluorimeters September 1971 S. S. BROWN and A. H. GOWENLOCK

24 Simple tests to detect poisons March 1972 B. w. MEADE et al.

25 Blood gas analysers May 1972 K. DIXoN

26 Kits for enzyme activity determination September 1972 S. B. ROSALKI and D. TARLOW

27 Assessment of pumps suitable for incorporation into existing continuous flow analytical systems November 1972 A. FLECK et al.
28 Routine clinical measurements of transferrin in human serum September 1973 K. DIXON

29 Control materials for clinical biochemistry (5th edition) September 1973 J. F. STEVENS

30 Notes on the quality of performance of serum cholesterol assays September 1973 S. S. BROWN

31 Determination of uric acid in blood and in urine July 1974 R. W. E. WATTS

32 A survey of amino acid analysers readily available in the United Kingdom September 1974 J. E. CARLYLE and P. PURKISS

33 Definitions of some words and terms used in automated analysis November 1974 A. FLECK, R. ROBINSON, S. S. BROWN, and J. R. HOBBS

34 Measurement of albumin in the sera of patients January 1975 LINDA SLATER, P. M. CARTER, and J. R. HOBBS

35 Investigation of the validity of temperature correction factors for serum aspartate and alanine transaminases March 1975 s. B. ROSALKI et al.

36 Factors influencing the assay of creatinine November 1975 J. G. H. COOK

37 A survey of enzyme reaction rate analysers readily available in the United Kingdom July 1977 R. A. SAUNDERS and R. F. BURNS

38 Transport of specimens for clinical chemistry analysis November 1977 P. WILDING, J. F. ZIIVA, and C. E. WILDE 